\title{
Response of 'Italian Riesling' Leaf Nitrogen Status and Fruit Composition (Vitis vinifera L.) to Foliar Nitrogen Fertilization
}

\author{
Danijela Janjanin \\ Institute of Agriculture and Tourism, Karla Huguesa 8, 52440 Poreč, Croatia \\ Marko Karoglan ${ }^{1}$ and Mirjana Herak Ćustić \\ Faculty of Agriculture, University of Zagreb, Svetošimunska cesta 25, 10000 \\ Zagreb, Croatia
}

Marijan Bubola

Institute of Agriculture and Tourism, Karla Huguesa 8, 52440 Poreč, Croatia

Mirela Osrečak and Igor Palčić

Faculty of Agriculture, University of Zagreb, Svetošimunska cesta 25, 10000 Zagreb, Croatia

Additional index words. Vitis vinifera, foliar nitrogen fertilization, leaf nitrogen status, fruit composition, free amino nitrogen, ammonia, yeast assimilable nitrogen

\begin{abstract}
Two-year study was conducted on Italian Riesling cultivar with the aim to compare the effect of foliar sprays with different nitrogen forms on grapevine leaf $\mathrm{N}$ status, yield, and nitrogen compounds in grape juice. Treatments included no fertilization (control), soil NPK treatment, and three foliar treatments [amino acids, urea, ammonia $\left(\mathrm{NH}_{4}^{+}\right) /$nitrate] applied four times during season, also treated with soil NPK. The application of $1 \% \mathrm{w} / \mathrm{v}$ urea significantly increased leaf total leaf $\mathrm{N}$ content in the second year of study. However, there were no effects on $\mathrm{N}$ compounds in grape juice, since changes in free amino nitrogen (FAN), $\mathrm{NH}_{4}^{+}$, and consequently yeast assimilable nitrogen (YAN) were not consistent among the treatments and experimental years. Although increase of vine leaf $\mathrm{N}$ status was achieved by $1 \% \mathrm{w} / \mathrm{v}$ urea, additional modifying of application time (by moving it closer to veraison) is needed, with the aim to increase $\mathbf{N}$ compounds in grape juice as well.
\end{abstract}

Nitrogen is a macronutrient with major role in plant growth as it is a constitutive part of nucleic acids, chlorophyll, amino acids, and therefore essential for the cell proliferation during intensive vegetative growth (Jackson, 2000). Moreover, nitrogen is required during alcoholic fermentation of must since yeasts use it for their cell growth (Keller, 2010). Its deficiency can cause stuck or sluggish fermentation (Jiranek et al., 1995). Content of nitrogen compounds in must also affects formation of volatile compounds during alcoholic fermentation (Barbosa et al., 2009, 2012).

Nitrogen fertilization is a regular viticultural practice proved to be affecting vine yield (Bell and Henschke, 2005; Smart and Robinson, 1991; Spayd et al., 1993), grape ripening and fruit composition (Christensen et al., 1994; Linsenmeier et al., 2008; Spayd et al., 1994), must nitrogen compounds (Linsenmeier et al., 2008; Neilsen et al., 2010; Schreiner et al., 2014) as well as grape

Received for publication 4 Dec. 2015. Accepted for publication 26 Jan. 2016.

${ }^{1}$ Corresponding author. E-mail: mkaroglan@ agr.hr. considering effect on grape amino acid content (Garde-Cerdan et al., 2014).

Foliar $\mathrm{N}$ application can also be considered as a tool for improvement of wine sensory characteristics since positive effect on grape volatile composition (Garde-Ceradan et al., 2014) and enhancement of grape and wine phenolic content (Portu et al., 2015a, 2015b) have been determined.

However, comparison of foliarly applied different $\mathrm{N}$ forms did not include the study of their effect on vine $\mathrm{N}$ supply, in addition to their effect on grape amino acid content.

Also, as previously reported, foliar nitrogen application is usually performed around veraison (Cheng et Martinson, 2009; Jreij et al., 2009; Lacroux et al., 2008), which proved to be an effective way to improve berry YAN content since nitrogen translocation in that period is directed mainly to berries. However, in vineyards with general nitrogen deficiency caused by both soil and grapevine low $\mathrm{N}$ status that can occur as a problem since general improvement of nitrogen vine supply is required.

As suggested by Neilsen et al. (2010) and Tozzini et al. (2013), earlier N application could affect both leaf and berry $\mathrm{N}$ accumulation. Research on late spring-applied (Conradie, 1990) and early summer-applied (Conradie, 1991) nitrogen showed that $\mathrm{N}$ translocation was mainly directed to bunches. Additionally, fall nitrogen fertilization also proved to be efficient in improving petiole $\mathrm{N}$ status (Peacock et al., 1991) or berry YAN supply (Hannam et al., 2014).

For this trial, vineyard with a history of low nitrogen status causing difficulties during alcoholic fermentation was selected. Therefore, multiple foliar nitrogen application was investigated, to generally improve grapevine nitrogen supply as well as berry $\mathrm{N}$ content.

The objective of this study was to compare effectiveness of different nitrogen forms (amino acids, urea, $\mathrm{NH}_{4}^{+} /$nitrate) in improving vine $\mathrm{N}$ supply and berry nitrogen compounds when foliarly applied several times during season. Due to increasing use of some commercial fertilizers, one commercial product containing amino acids was included in this study.

\section{Materials and Methods} authors who considered different ways to improve nitrogen soil availability, utilization, grapevine supply and hence alcoholic fermentation (Bell and Robson, 1999; Christensen et al., 1994; Conradie, 1992; Holzapfel and Treeby, 2007; Schreiber et al., 2002).

In recent years, foliar nitrogen application occurred as additional way of improvement of nitrogen fertilization since it is less dependent on weather conditions (Jreij et al., 2009) and less harmful to environment, considering nitrate soil leaching (Dong et al., 2005; Schreiber et al., 2002). Several experiments of foliar use of different $\mathrm{N}$ forms have been reported, including comparison of urea, nitrate, and $\mathrm{NH}_{4}{ }^{+}$(Porro et al., 2010). Moreover, foliarly applied proline, phenylalanine, and urea were compared with commercial nitrogen fertilizers,
Vineyard site and plant material. Twoyear study (2012 through 2013) was conducted on Italian Riesling cultivar at Jazbina experimental field (Faculty of Agriculture, University of Zagreb, long. $45^{\circ} 51^{\prime} \mathrm{N}$, lat. $\left.16^{\circ} 0^{\prime} \mathrm{E}\right)$, which is characterized by moderately warm and rainy continental climate. Experimental vines were planted in 1997 with row spacing of 1.2 between vines $x$ $2 \mathrm{~m}$ between rows (4167 vines/ha), oriented east-west. Soil type was anthropogenic pseudogley with clay texture.

Meteorological data were collected at Zagreb Maksimir station, $5 \mathrm{~km}$ from experimental site.

Growing season 2012 had total amount of 1857 growing degree day (GDD), with average 
growing season temperature of $18.5^{\circ} \mathrm{C}$. Growing season precipitation was $532.5 \mathrm{~mm}$ unevenly spread through the ripening season, which was especially notable in August when only $9.8 \mathrm{~mm}$ of precipitation was measured. Growing season 2013 was quite cooler, having total of 1718 GDD with $17.8{ }^{\circ} \mathrm{C}$ average growing season temperature. Growing season precipitation was $518.4 \mathrm{~mm}$, which in addition to lower temperatures lead to later harvest (25 Sept.) compared with 2012 (18 Sept.).

'Italian Riesling' vines (clone ISV-1) were grafted on SO4 rootstock. Vines were trained to double Guyot, leaving 24 buds per vine. Fruit-bearing wire was set to $80 \mathrm{~cm}$ aboveground, with addition of two sets of catch wires at $40 \mathrm{~cm}$ intervals from the fruitbearing wire.

Vineyard was not irrigated and no fertilization was applied 1 year before experiment.

Soil analysis performed during winter period before first experimental year showed that it was very acid with a surface $\mathrm{pH}$ (in $\mathrm{KCl}$ ) of 4.1 ( 0 to $30 \mathrm{~cm}$ deep). The soil was very poor in organic matter, ranging from $0.9 \%$ (0 to $30 \mathrm{~cm}$ deep) to $1.6 \%$ (30 to $60 \mathrm{~cm}$ deep). The lower horizon of soil was richer in organic matter due to the trenching of soil up to $60 \mathrm{~cm}$ deep, performed before the planting of vines. Available $\mathrm{P}$ was lower than $4 \mathrm{mg}$ of $\mathrm{P}_{2} \mathrm{O}_{5} / 100 \mathrm{mg}$ soil. Available $\mathrm{K}$ did not exceeded $12 \mathrm{mg}$ of $\mathrm{K}_{2} \mathrm{O} / 100 \mathrm{mg}$ soil. The soil was moderately supplied with nitrogen, ranging from $0.06 \%(0$ to $30 \mathrm{~cm}$ deep) to $0.1 \%$ ( 30 to $60 \mathrm{~cm}$ deep). Following soil analysis, mineral fertilizer $7 \mathrm{~N}-$ 8.7P-24.9K was applied to entire experimental plot except control vines.

Viticultural practice during season, usual for this viticultural area, was performed. Application of glyphosate was used in aim to keep the soil beneath the vine rows weedfree. Shoots exceeding the height of the trellis were hedged to $20 \mathrm{~cm}$ above the last wire, 4 weeks before veraison. Vines were not subjected to irrigation treatment.

This vineyard site was selected for experiment because of repeating low must YAN content in years before experiment, which indicated low vine N supply. Study with different levels of urea soil application was performed (Karoglan, 2009); however, satisfactory YAN level was not achieved.

Treatments and experimental design. This single-factor experiment consisted of five fertilization levels, designed as latin square. Each repetition included 18 continuous vines. Experiment had a total of 25 units (plots) distributed in five rows, with nontreated rows between experimental ones.

With the aim to compare foliar sprays of different nitrogen forms, using fertilizers frequently used in local viticultural practice, following sprays were applied: amino acids $\left(\right.$ Drin $^{\circledR}$, Green Has Italia, Canale d'Alba, Italy), urea (urea), and $\mathrm{NH}_{4}^{+} /$nitrate (ammonium nitrate) containing $6.3 \%, 46 \%$, and $17.5 \%$ nitrogen, respectively. Treatments were five levels of fertilization as follows: 1) control without fertilization (C), 2) early-season soil application of $250 \mathrm{~kg} / \mathrm{ha} 7 \mathrm{~N}-8.7 \mathrm{P}-24.9 \mathrm{~K}$ (NPK) (3) NPK treatment with addition of foliar amino acids applications $(0.25 \% \mathrm{w} / \mathrm{v}$ Drin), (DR), (4) NPK treatment with addition of foliar urea applications $(1 \% \mathrm{w} / \mathrm{v}$ urea) (UR), and (5) NPK treatment with addition of ammonium/nitrate applications $(0.25 \% \mathrm{w} / \mathrm{v}$ ammonium nitrate) (AN). Application of commercial products with different $\mathrm{N}$ content, applied in concentration following manufacturers' recommendation led to different $\mathrm{N}$ quantities. However, intention was to directly evaluate practical effectiveness of applied fertilizers, based on the results of experiment.

Foliar applications were repeated at four growth stages: young shoot with eight leaves separated, before flowering, berries pea size, and after harvest, which represent stage 15, 18,31 , and 41 according to modified Eichorn and Lorenz system (Coombe, 1995). Fertilizers were applied using backpack sprayer until runoff. Sprays containing $\mathrm{N}$ were applied in $926 \mathrm{~L} \cdot \mathrm{ha}^{-1}$ of water. The rates of $\mathrm{N}$ were $17.04 \mathrm{~kg} \mathrm{~N} / \mathrm{ha} /$ year for UR treatment, $1.64 \mathrm{~kg} \mathrm{~N} / \mathrm{ha} /$ year for $\mathrm{AN}$ treatment, and $0.60 \mathrm{~kg} \mathrm{~N} / \mathrm{ha} /$ year for DR treatment. In both years, foliar sprays were applied early in the day (before 12:00 AM), so temperatures never exceeded $25^{\circ} \mathrm{C}$ during treatment application. There were no leaf damages observed after treatment application.

Leaf nitrogen measurements. Before every foliar application leaf samples were collected, consisting 10 visually healthy opposite basal cluster leaves per each repetition, positioned between nodes 2 and 4. Leaves were collected according to standard method for leaf diagnosis that recommends sampling of blades opposite the basal clusters, established by the Organisation Internationale de la Vigne et du Vin (OIV, 1996). The leaves were dried at $105^{\circ} \mathrm{C}$ according to Wermelinger and Koblet (1990). The total leaf nitrogen was determined according to Kjeldahl method (AOAC, 1995).

Yield components and juice analysis. Grapes were harvested at their full maturity when the total soluble solids $(\% \mathrm{SS})$ of 100 randomized collected berries remained constant for a few days, which was on 18 Sept. 2012 [261 day of the year (DOY)] and 25 Sept. 2013 (268 DOY).

Number of clusters and yield per vine were determined. Cluster weight, yield per vine, and yield per hectare were calculated based on collected data.

Clusters were separately destemmed and crushed for each experimental plot and submitted to juice analysis. \%SS were measured using handheld refractometer (MASTER-OE; Atago, Tokyo, Japan). Titratable acidity (TA, $\mathrm{g} \cdot \mathrm{L}^{-1}$ ) was measured by titration with $0.1 \mathrm{M}$ $\mathrm{NaOH}$ according to OIV (2013) method. Additionally, samples were taken for each repetition and frozen at $-18{ }^{\circ} \mathrm{C}$ for following juice analysis of nitrogen compounds.

Juice nitrogen compounds. Frozen juice samples were thawed at room temperature $\left(21^{\circ} \mathrm{C}\right)$ to determine content of must nitrogen compounds. FAN content $\left(\mathrm{mg} \cdot \mathrm{L}^{-1}\right)$ was determined using ultraviolet spectrophotometer (SPECORD 400; Analytik Jena AG, Jena,
Germany), by nitrogen by o-phthaldialdehyde assay (NOPA) procedure according to Dukes and Butzke (1998). $\mathrm{NH}_{4}{ }^{+}$content (mg. $\mathrm{L}^{-1}$ ) was measured with Megazyme Ammonia Assay Kit and procedure (Megazyme, Chicago, IL), according to the method of Bergmeyer and Beutler (1990), using ultraviolet spectrophotometer (SPECORD 400). YAN (mg. $\mathrm{L}^{-1}$ ) was calculated as a sum of FAN and $\mathrm{NH}_{4}^{+}$content.

Statistical analysis. All variables were analyzed by one-way analysis of variance, using foliar spray treatments as factors. Data were examined separately by year. Treatment means were compared using Fisher's least significant difference test to establish whether there were significant differences among treatments $(P \leq 0.05)$. All statistical analysis were conducted using Statistica software (Version 5.0; Statsoft Inc., Tulsa, OK).

\section{Results}

Vine nitrogen supply. Vine leaf nitrogen supply affected by foliar-applied different nitrogen forms is indicated by leaf total $\mathrm{N}$ (\%) (Table 1). Before first foliar application, average leaf total $\mathrm{N}$ level in experimental vineyard was very high, $3.43 \%$. The results considering vine nitrogen supply as affected by fertilization treatments were not consistent, especially throughout first year of experiment. Additionally, vine nitrogen supply showed different dynamics through vegetative period of first and second experimental year. In 2012, highest average leaf total $\mathrm{N}$ value was at the beginning of the season and afterward was decreasing toward the end of vegetation period. Contrary, in 2013, it peaked at "berries pea size" stage and decreased afterward toward lowest average value at "after harvest" growth stage.

In 2012, foliar treatments did not significantly affect vine nitrogen supply although some significant differences regarding leaf total $\mathrm{N}$ occurred at prebloom and after harvest growth stages.

No significant difference was recorded at "berries pea size" stage although leaf total $\mathrm{N}$ was increased by UR and AN treatments. However, that increase was nonsignificant neither it repeated at other recorded growth stages.

In 2013, average leaf total $\mathrm{N}$ in foliar treatments was higher than in nonfoliar treatments in all growth stages except at the beginning of season ("eight leaves separated" stage).

Also, leaf total $\mathrm{N}$ was significantly increased by UR treatment at all observed stages except "eight leaves separated" when slightly higher value was obtained by DR, compared with other treatments. At "eight leaves separated" growth stage, slightly increased leaf total $\mathrm{N}$ value by $\mathrm{C}$ treatment indicates there was no effect due to foliar treatments from first experimental year.

Yield components and juice quality. None of the fertilization treatments had clear and consistent influence on yield parameters (Table 2). However, during first experimental year, slightly higher values occurred within 
Table 1. Effect of nitrogen foliar treatments on vine leaf nitrogen status indicated by leaf total $\mathrm{N}(\%)$.

\begin{tabular}{lcccc}
\hline Treatments $^{\mathrm{z}}$ & 8 Leaves separated & Prebloom & Berries pea size & After harvest \\
\hline C & & Year 2012 & & \\
NPK & 3.43 & $3.04 \mathrm{a}$ & 2.27 & $1.78 \mathrm{a}$ \\
DR & & $3.09 \mathrm{a}$ & 2.33 & $1.75 \mathrm{a}$ \\
UR & $3.05 \mathrm{a}$ & 2.33 & $1.65 \mathrm{~b}$ \\
AN & $3.01 \mathrm{ab}$ & 2.39 & $1.66 \mathrm{~b}$ \\
Significance & & $2.89 \mathrm{~b}$ & 2.38 & $1.75 \mathrm{a}$ \\
& & $* *$ & NS & $* * *$ \\
C & & Year 2013 & & \\
NPK & & $2.92 \mathrm{~b}$ & $3.62 \mathrm{c}$ & $1.50 \mathrm{~b}$ \\
DR & 3.58 & $2.92 \mathrm{~b}$ & $3.84 \mathrm{bc}$ & $1.48 \mathrm{~b}$ \\
UR & 3.50 & $3.03 \mathrm{ab}$ & $3.82 \mathrm{bc}$ & $1.52 \mathrm{~b}$ \\
AN & 3.60 & $3.11 \mathrm{a}$ & $4.11 \mathrm{a}$ & $1.61 \mathrm{a}$ \\
Significance & 3.50 & $2.99 \mathrm{ab}$ & $4.01 \mathrm{ab}$ & $1.54 \mathrm{ab}$ \\
N & 3.52 & $*$ & $* * *$ & $* *$ \\
\hline
\end{tabular}

${ }^{\mathrm{z}} \mathrm{NPK}, \mathrm{DR}, \mathrm{UR}$, and AN indicate treatments of soil application of $250 \mathrm{~kg} / \mathrm{ha}$ of NPK fertilizer, NPK treatment with addition of foliar amino acids applications $(0.25 \% \mathrm{w} / \mathrm{v}$ Drin $)$, NPK treatment with addition of foliar urea applications $(1 \% \mathrm{w} / \mathrm{v}$ urea), and NPK treatment with addition of ammonium/ nitrate applications $(0.25 \% \mathrm{w} / \mathrm{v}$ ammonium nitrate), respectively. $\mathrm{C}$ indicates control treatment without fertilization.

${ }^{\mathrm{y}}$ Results of analysis of variance: ${ }^{\mathrm{Ns},}{ }^{*,}{ }^{* * *},{ }^{* * *}$ Nonsignificant or significant difference at $P \leq 0.05,0.01$, and 0.001 , respectively.

Means in a column followed by the same letter are not significantly different at $P \leq 0.05$ by least significant difference test.

Table 2. Effect of nitrogen foliar treatments on yield components and juice quality.

\begin{tabular}{|c|c|c|c|c|c|c|}
\hline Treatments $^{z}$ & Clusters/vine & Cluster wt (g) & Yield (kg/vine) & Yield (t/ha) & SS (\%) & $\overline{\mathrm{TA}(\mathrm{g} / \mathrm{L})}$ \\
\hline \multicolumn{7}{|c|}{ Year 2012} \\
\hline Control & 36.7 & 77.4 & 2.82 & 11.8 & $22.7 \mathrm{~b}$ & $5.5 \mathrm{a}$ \\
\hline NPK & 36.5 & 81.7 & 3.00 & 12.5 & $24.0 \mathrm{ab}$ & $5.4 \mathrm{ab}$ \\
\hline DR & 39.9 & 84.3 & 3.38 & 14.1 & $24.3 \mathrm{a}$ & $5.0 \mathrm{~b}$ \\
\hline UR & 40.1 & 79.7 & 3.26 & 13.6 & $23.5 \mathrm{ab}$ & $5.5 \mathrm{a}$ \\
\hline AN & 45.0 & 74.3 & 3.36 & 14.0 & $23.4 \mathrm{ab}$ & $5.4 \mathrm{ab}$ \\
\hline Significance ${ }^{y}$ & NS & NS & NS & NS & $*$ & $* *$ \\
\hline \multicolumn{7}{|c|}{ Year 2013} \\
\hline Control & 26.0 & 112.6 & 2.88 & 12.0 & 23.2 & 6.9 \\
\hline NPK & 28.7 & 98.1 & 2.78 & 11.6 & 24.2 & 6.5 \\
\hline DR & 25.7 & 102.8 & 2.66 & 11.1 & 25.4 & 7.2 \\
\hline UR & 25.9 & 106.0 & 2.79 & 11.6 & 24.0 & 6.7 \\
\hline AN & 25.0 & 98.7 & 2.47 & 10.3 & 24.4 & 6.5 \\
\hline Significance & NS & NS & NS & NS & NS & NS \\
\hline
\end{tabular}

${ }^{\mathrm{z}} \mathrm{NPK}, \mathrm{DR}, \mathrm{UR}$, and AN indicate treatments of soil application of $250 \mathrm{~kg} / \mathrm{ha}$ of NPK fertilizer, NPK treatment with addition of foliar amino acids applications $(0.25 \% \mathrm{w} / \mathrm{v}$ Drin), NPK treatment with addition of foliar urea applications ( $1 \% \mathrm{w} / \mathrm{v}$ urea), and NPK treatment with addition of ammonium/ nitrate applications $(0.25 \% \mathrm{w} / \mathrm{v}$ ammonium nitrate), respectively. $\mathrm{C}$ indicates control treatment without fertilization.

${ }^{\mathrm{y}}$ Results of analysis of variance: ${ }^{\mathrm{Ns}},{ }^{*},{ }^{* *},{ }^{* * *}$ Nonsignificant or significant difference at $P \leq 0.05,0.01$, and 0.001 , respectively.

Means in a column followed by the same letter are not significantly different at $P \leq 0.05$ by least significant difference test.

foliar nitrogen treatments compared with nonfoliar ones, in all measured parameters except cluster weight. In 2013, regardless of treatment, yield parameters obtained lower values than in 2012, although average cluster weight was higher.

Also, contrary to 2012, in second experimental year, $\mathrm{C}$ treatment, compared with foliar treatments, obtained slightly higher values in all measured parameters.

Juice quality was changed under the influence of some fertilization treatments, although not always reflecting results concerning yield components (Table 2).

The highest \%SS value, indicating earlier ripening, in both experimental years was obtained in DR treatment, contrary to C treatment, which obtained the lowest \%SS value. However, the difference between those treatments was significant only in the first experimental year. This could also be addressed to meteorological data, since 2012 year was
In year 2012, average $\mathrm{FAN}$ and $\mathrm{NH}_{4}{ }^{+}$content in YAN was $63 \%$ and $37 \%$, respectively. Individual nitrogen compounds were, as well as YAN, the most abundant in the $\mathrm{C}$ treatment, which significantly increased FAN content compared with all other treatments except DR. On the other hand, regarding $\mathrm{NH}_{4}{ }^{+}$content, UR treatment was the only one not significantly lower than C. Year 2013 was specific for extremely low values of all measured must nitrogen compounds. YAN content in must was 2-fold or even lower than values measured in 2012. Likewise in first experimental year, average FAN content in YAN was higher $(71 \%)$ than $\mathrm{NH}_{4}^{+}$content (29\%). Contrary to 2012 results, highest FAN and YAN content in 2013 were obtained by AN treatment (Table 3), whereas $\mathrm{NH}_{4}{ }^{+}$content was slightly higher within UR treatment. Nevertheless, all nitrogen compounds obtained very similar values among treatments and consequently no significant differences occurred due to fertilization in 2013.

\section{Discussion}

Average leaf nitrogen level in experimental grapevines at the beginning of experiment exceeded expectations, especially considering low soil $\mathrm{N}$ supply and low must yeast available amino-N in years preceding this experiment (Karoglan, 2009). It also exceeds average vine leaf $\mathrm{N}$ level, which ranges from $1 \%$ to $2 \%$ (Coombe and Dry, 1992).

Soluble solids showed some changes in response to foliar fertilization, especially to DR treatment, which affected the highest \% SS value in both years. The observed increase is not irrelevant when compared with $\mathrm{C}$, since DR grapes show potential to yield wines with more than 1.0 vol\% higher alcohols than $\mathrm{C}$ grapes.

The most notable effects of foliar nitrogen application were slightly increased values of yield parameters in the first experimental year and improved vine $\mathrm{N}$ supply (indicated by leaf total $\mathrm{N}$ ) in the second year. Improved vine leaf nitrogen supply was to the largest extent due to UR treatment. Impact of UR on leaf total $\mathrm{N}$ increase is probably due to the greatest content of $\mathrm{N}$ applied with UR treatments $(1 \% \mathrm{w} / \mathrm{v})$.

Significantly higher leaf total $\mathrm{N}$ was determined at some stages, which indicates positive impact of application at growth stages: eight leaves separated, prebloom, and berries pea size. Foliar application after harvest intended to increase vine leaf $\mathrm{N}$ supply at the beginning of vegetative growth following year ("eight leaves separated" stage) since late-season $\mathrm{N}$ application previously occurred as an effective way to improve vine leaf $\mathrm{N}$ supply at early stages of the following year (Christensen et al., 1994; Holzapfel and Treeby 2007; Xia et Cheng, 2004). Differently, in some studies it provided only small increase of vine leaf $\mathrm{N}$ supply (Brunetto et al., 2005). Our study confirms latter findings since leaf total $\mathrm{N}$ was not improved by "after harvest" foliar treatments. No significant differences occurred at this stage, except slightly 
Table 3. Effect of nitrogen foliar treatments on must nitrogen compounds.

\begin{tabular}{|c|c|c|c|}
\hline Treatments $^{\mathrm{z}}$ & $\begin{array}{c}\text { Free primary } \\
\text { amino-N }\left(\mathrm{mg} \cdot \mathrm{L}^{-1}\right)\end{array}$ & $\begin{array}{c}\text { Ammonia } \\
\left(\mathrm{mg} \cdot \mathrm{L}^{-1}\right)\end{array}$ & $\begin{array}{c}\text { Yeast available } \\
\text { amino-N }\left(\mathrm{mg} \cdot \mathrm{L}^{-1}\right)\end{array}$ \\
\hline \multicolumn{4}{|c|}{ Year 2012} \\
\hline Control & $40.2 \mathrm{a}$ & $28.4 \mathrm{a}$ & $68.6 \mathrm{a}$ \\
\hline NPK & $28.3 \mathrm{~b}$ & $13.6 \mathrm{~b}$ & $41.9 \mathrm{~b}$ \\
\hline DR & $31.2 \mathrm{ab}$ & $12.3 \mathrm{~b}$ & $43.5 \mathrm{~b}$ \\
\hline UR & $26.1 \mathrm{~b}$ & $21.4 \mathrm{ab}$ & $47.5 \mathrm{ab}$ \\
\hline AN & $28.7 \mathrm{~b}$ & $16.5 \mathrm{~b}$ & $45.2 \mathrm{~b}$ \\
\hline Significance ${ }^{y}$ & $* *$ & $*$ & $* *$ \\
\hline \multicolumn{4}{|c|}{ Year 2013} \\
\hline Control & 14.2 & 5.0 & 19.2 \\
\hline NPK & 13.6 & 5.9 & 19.5 \\
\hline DR & 15.2 & 6.0 & 21.2 \\
\hline UR & 14.0 & 7.0 & 21.0 \\
\hline $\mathrm{AN}$ & 16.7 & 6.1 & 22.8 \\
\hline Significance & NS & NS & NS \\
\hline
\end{tabular}

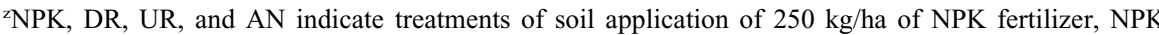
treatment with addition of foliar amino acids applications $(0.25 \% \mathrm{w} / \mathrm{v}$ Drin $)$, NPK treatment with addition of foliar urea applications ( $1 \% \mathrm{w} / \mathrm{v}$ urea), and NPK treatment with addition of ammonium/nitrate applications $(0.25 \% \mathrm{w} / \mathrm{v}$ ammonium nitrate), respectively. $\mathrm{C}$ indicates control treatment without fertilization.

${ }^{\mathrm{y}}$ Results of analysis of variance: ${ }^{\mathrm{Ns},}{ }^{*},{ }^{* *},{ }^{* * *}$ Nonsignificant or significant difference at $P \leq 0.05,0.01$, and 0.001 , respectively.

Means in a column followed by the same letter are not significantly different at $P \leq 0.05$ by least significant difference test.

increased leaf total $\mathrm{N}$ for $\mathrm{DR}$, as well as $\mathrm{C}$ treatment. Rather high values of $\mathrm{N}$ supply in vine leaves from $\mathrm{C}$ treatment with no fertilization imply the ongoing effect of previous vine $\mathrm{N}$ supply. Therefore, it is not strange that effects of ongoing $\mathrm{N}$ fertilization are still to be developed.

The response of experimental vines to foliar treatments was inconsistent across years. Such varying results are in accordance to other findings, where positive effect of $\mathrm{N}$ fertilization was not recorded through every year of research (Bell and Robson, 1999; Linsenmeier et al., 2008; Neilsen et al., 2010). Obtained differences, however, are most likely to be related to previous vine nitrogen supply accumulated in years preceding experiment, rather than foliar fertilization since the C and NPK treatments (as well as DR treatment) obtained slightly higher leaf total $\mathrm{N}$. It can also be a consequence of vineyard heterogeneity.

Also, this study has results similar to some other studies where no effect of $\mathrm{N}$ treatments (in the form of urea) on vine $\mathrm{N}$ status was observed (Hannam et al., 2014; Jreij et al., 2009). However, it is important to point out that, in mentioned studies, foliar application was performed at veraison and, consequently, increased berry $\mathrm{N}$ compounds. Such findings point out the need to modify foliar application time to target particular vineyard needs.

No significant differences were observed considering yield parameters. It is in accordance to previous studies (Hannam et al., 2014; Lacroux et al., 2008; Tozzini et al., 2013), where foliar $\mathrm{N}$ application had no effect on yield parameters, which is expected since application was performed at veraison when grape composition, rather than yield, is affected.

Although application time in our study was different, lack of significant difference, considering yield parameters, is also not unusual. According to Bell and Henschke
(2005), $\mathrm{N}$ fertilization, depending on sufficient or nonsufficient vine $\mathrm{N}$ supply, has a positive or negative effect on vegetative growth and yield, respectively. Other authors observed no increase in yield (Lohnertz, 1991) or decrease of yield (Champagnol, 1994) when vine N supply was sufficient.

Despite no significant effect on yield, fertilization seemed to have affected yield parameters in other way. Second year of our study resulted in generally lower yield than 2012, despite higher cluster weight. Higher cluster weight could have been the consequence of very high precipitation in August of 2013, when $145.2 \mathrm{~mm}$ of precipitation was measured. This was the trigger for later powdery mildew occurrence, which could lead to lowering yield to some extent. Linsenmeier et al. (2008) explained that abundant $\mathrm{N}$ supply leads to decrease of fruit set and therefore to lower yield. Additionally, the berry set period in 2012 had more precipitation, that, compared with 2013, led to higher $\mathrm{N}$ soil availability. Therefore, nonsufficient vine $\mathrm{N}$ supply, powdery mildew, and weather conditions could have all contributed to generally lower yield in 2013 .

Average FAN content in total must YAN (63\% and $71 \%$ in 2012 and 2013, respectively) is in accordance to Kliewer (1969) who established that amino acids make $60 \%$ to $90 \%$ of total must nitrogen.

However, YAN values in must, regardless of treatment, were below expected values in both experimental years, especially in 2013 . This could be explained by lower temperatures recorded in 2013, since some positive effects of foliar sprays on berry $\mathrm{N}$ content have been obtained in warmer climate (Lasa et al., 2012). The ripening period of 2013 was also characterized by higher precipitation that may cause leaching loss of $\mathrm{N}$ from the soil profile. According to literature (Bell and Henschke, 2005; Jiranek et al., 1995), $140 \mathrm{mg} \cdot \mathrm{L}^{-1}$ is minimum of YAN content in must, required to avoid fermentation faults (slow, stuck, or sluggish fermentation). Below that threshold, rate or time for completion of fermentation is unsatisfactory (Jiranek et al., 1995). YAN values reported by other authors (Garde-Cerdan et al., 2014; Linsenmeier et al., 2008; Spayd et al., 1994) are usually around $200 \mathrm{mg} \cdot \mathrm{L}^{-1}$ or higher. Another survey (Butzke, 1998) of YAN status in 1523 clarified musts from 968 different cultivars showed that that the average was $213 \mathrm{mg} \cdot \mathrm{L}^{-1}$. Although YAN values used by Saccharomyces cerevisiae can vary and are dependent on other factors such as yeast strain (Taillandier et al., 2007) and grape juice total SS (\%) (Barbosa et al., 2009), in this study unobstructed fermentation could not have been expected. This problem can still be solved by must supplementation with added nitrogen or using yeast strains with a low nitrogen demand.

Previous findings showed that nitrogen fertilization applied either to the soil (Linsenmeier et al., 2008; Spayd et al., 1994) or foliarly (Hannam et al., 2014; Jreij et al., 2009; Tozzini et al., 2013) increases must total $\mathrm{N}$ content as well as individual $\mathrm{N}$ compounds.

However, $\mathrm{N}$ foliar application did not always give consistent and repeated results, regarding juice $\mathrm{N}$ compounds. In Lasa et al. (2012) study, increase of juice $\mathrm{N}$ compounds (YAN and total amino acid) after foliar urea application depended on season as well as on time of application, with later applications (veraison or 3 weeks after veraison) being more effective in increasing juice $\mathrm{N}$ compounds than application 3 weeks before veraison. Mengel (2002) also stated that foliar-applied $\mathrm{N}$ may be more effectively absorbed at veraison due to cracks in epicuticular waxes in old leaves that can facilitate absorption. Success of N uptake considering the time of application can also depend on variety (Porro et al., 2006).

In addition to previously mentioned need for modifying the time of foliar $\mathrm{N}$ application, we can assume that additional application at veraison is needed to increase berry/ must $\mathrm{N}$ compounds level, given the particular needs of our experimental vineyard. Possibly, spring foliar fertilization performed in the current study could be reduced to fewer numbers of applications. Increasing the concentrations of nitrogen fertilizers solutions may also solve a problem, keeping in mind that grape leaves are susceptible to burning when concentrations are high.

Finally, the present study as well as many previous results (Garde-Cerdan et al., 2014; Lacroux et al., 2008; Lasa et al., 2012; Portu et al., 2015a, 2015b) lead us to conclusion that nitrogen foliar application does not always show clear and consistent effect on grape composition, since the results tend to vary within the different experiments.

\section{Conclusion}

Nitrogen foliar sprays were only partially effective with increasing grapevine leaf $\mathrm{N}$ status. Expected increase of juice $\mathrm{N}$ 
compounds was not achieved. The effects of different $\mathrm{N}$ forms via foliar sprays were mostly nonsignificant; however, all $\mathrm{N}$ forms foliarly applied somewhat increased leaf total $\mathrm{N}$ in most stages of second experimental year. Moreover, urea foliar sprays $(1 \% \mathrm{w} / \mathrm{v})$ significantly increased leaf total $\mathrm{N}$ in the second year of study. Improvements in vine $\mathrm{N}$ status were not sufficient to increase YAN above recommended $140 \mathrm{mg} \cdot \mathrm{L}^{-1}$. It remains questionable how much of applied $\mathrm{N}$ is retained by vine contrary to translocation toward clusters, since grape juice composition changes were not consistent among foliar treatments. Lack of impact on juice $\mathrm{N}$ composition requires additional modifying of application time by moving one of application terms closer to veraison, so increase of juice $\mathrm{N}$ compounds can be achieved as well.

\section{Literature Cited}

Arias-Gil, M., T. Garde-Cerdan, and C. AncinAzpilicueta. 2007. Influence of addition of ammonium and different amino acid concentrations on nitrogen metabolism in spontaneous must fermentation. Food Chem. 103:1312-1318.

AOAC. 1995. Official methods of analysis of the Association of Official Analytical Chemists. 16th ed. AOAC International, Washington, DC.

Barbosa, C., V. Falco, A. Mendes-Faia, and A. Mendes-Ferreira. 2009. Nitrogen addition influences formation of aroma compounds, volatile acidity and ethanol in nitrogen deficient media fermented by Saccharomyces cerevisiae wine strains. J. Biosci. Bioeng. 108:99-104

Barbosa, C., A. Mendes-Faia, and A. MendesFerreira. 2012. The nitrogen source impacts major volatile compounds released by Saccharomyces cerevisiae during alcoholic fermentation. Intl. J. Food Microbiol. 160:87-93.

Bell, S.-J. and P.A. Henschke. 2005. Implications of nitrogen nutrition for grapes, fermentation and wine. Austral. J. Grape Wine Res. 11:242-295.

Bell, S.-J. and A. Robson. 1999. Effect of nitrogen fertilization on growth, canopy density, and yield of Vitis vinifera L. cv. Cabernet Sauvignon. Amer. J. Enol. Viticult. 50:351-358

Bergmeyer, H.U. and H.-O. Beutler. 1990. Ammonia, p. 454-461. In: H.U. Bergmeyer (ed.). Methods of enzymatic analysis, 3rd ed., Vol. VIII. VCH Publishers (UK) Ltd., Cambridge, UK.

Brunetto, G., J. Kaminski, G.W. Bastos de Melo, L.C. Gatiboni, and S. Urquiaga. 2005. Uptake and redistribution of nitrogen in foliar application in young grapevines. Rev. Bras. Fruticultura. 27:110-114.

Butzke, C.E. 1998. Survey of yeast assimilable nitrogen status in musts from California, Oregon, and Washington. Amer. J. Enol. Viticult. 49:220-224.

Champagnol, F. 1994. Facteurs agronomiques de l'acidite des mouts et des vins. Progres Agric. Vitic. 111:469-481.

Cheng, L. and T. Martinson. 2009. The effect of foliar nitrogen application on juice yeast available nitrogen in 'Riesling' depends on vine nitrogen status. HortScience 44:1060 (abstr.).

Christensen, L.P., M.L. Bianchi, W.L. Peacock, and D.J. Hirschfelt. 1994. Effect of nitrogen fertilizer timing and rate on inorganic nitrogen status, fruit composition, and yield of grapevines. Amer. J. Enol. Viticult. 45:377-387.

Conradie, W.J. 1990. Distribution and translocation of nitrogen absorbed during late spring by two-year-old grapevines grown in sand culture. Amer. J. Enol. Viticult. 41:241-250.

Conradie, W.J. 1991. Distribution and translocation of nitrogen absorbed during early summer by two-year-old grapevines grown in sand culture. Amer. J. Enol. Viticult. 42:180-190.

Conradie, W.J. 1992. Partitioning of nitrogen in grapevines during autumn and the utilisation of nitrogen reserves during the following growing season. S. Afr. J. Enol. Vitic. 13:45-59.

Coombe, B.G. 1995. Adoption of a system for identifying grapevine growth stages. Austral. J. Grape Wine Res. 1:104-110.

Coombe, B.G. and P.R. Dry. 1992. Viticulture Volume 2. Practices. Winetitles, Adelaide, Australia.

Dong, S., D. Neilsen, G.H. Neilsen, and L.H. Fuchigami. 2005. Foliar N application reduces soil $\mathrm{NO}^{3-}-\mathrm{N}$ leaching loss in apple orchards. Plant Soil 268:357-366.

Dukes, B.C. and C.E. Butzke. 1998. Rapid determination of primary amino acids in must using an OPA/NAC spectrophotometric assay. Amer. J. Enol. Viticult. 49:125-133.

Garde-Cerdan, T., R. Lopez, J. Portu, L. GonzalezArenzana, I. Lopez-Alfaro, and P. Santamaria. 2014. Study of the effects of proline, phenylalanine, and urea foliar application to Tempranillo vineyards on grape amino acid content. Comparison with commercial nitrogen fertilisers. Food Chem. 163:136-141.

Giorgessi, F., R. Flamini, A. Baruzzini, and A. Dalla Vedova. 2001. Effetto della concimazione sui contenuti di composti azotati nei mosti e di composti volatili di fermentazione nei vini (cv. Pinot b.). Riv. Vitic. Enol. 4:3-24

Hannam, K.D., G.H. Neilsen, D. Neilsen, W.S. Rabie, A.J. Midwood, and P. Millard. 2014. Late-season foliar urea applications can increase berry yeast-assimilable nitrogen in winegrapes (Vitis vinifera L.). Amer. J. Enol. Viticult. 65:89-95.

Holzapfel, B.P. and M.T. Treeby. 2007. Effects of timing and rate of $\mathrm{N}$ supply on leaf nitrogen status, grape yield and juice composition from Shiraz grapevines grafted to one of three different rootstocks. Austral. J. Grape Wine Res. 13:14-22.

Jackson, R.O. 2000. Wine science: Principles, practice, perception. 2nd ed. San Diego, CA, Academic Press.

Jiranek, V., P. Langridge, and P.A. Henschke. 1995. Amino acid and ammonium utilization by Saccharomyces cerevisiae wine yeasts from a chemically defined medium. Amer. J. Enol. Viticult. 46:75-83.

Jreij, R., M.T. Kelly, A. Deloire, E. Brenon, and A. Blaise. 2009. Combined effects of soil-applied and foliar-applied nitrogen on the nitrogen composition and distribution in water stressed Vitis vinifera L. cv. Sauvignon blanc grapes. J. Intl. Sci. Vigne Vin. 43:179-187.

Karoglan, M. 2009. The impact of nitrogen fertilization on must and wine composition of Italian Riesling, Chardonnay and White Riesling (Vitis vinifera L.). Faculty of Agr., Zagreb Univ., PhD Diss.

Keller, M. 2010. The science of grapevines: Anatomy and physiology. Academic Press, Elsevier Inc., Burlington, MA.
Kliewer, W. 1969. Free amino acids and other nitrogenous substances of table grape varieties. J. Food Sci. 34:274-278.

Lacroux, F., O. Tregoat, C. Van Leeuwen, A. Pons, T. Tominaga, V. Lavigne-Cruege, and D. Dubordieu. 2008. Effect of foliar nitrogen and sulphur application on aromatic expression of Vitis vinifera L. cv. Sauvignon blanc. J. Intl. Sci. Vigne Vin. 42:1-8.

Lasa, B., S. Menendez, K. Sagastizabal, M.E. Calleja Cervantes, I. Irigoyen, J. Muro, P.M. Aparicio-Tejo, and I. Ariz. 2012. Foliar application of urea to "Sauvignon Blanc" and "Merlot" vines: Doses and time of application. Plant Growth Regulat. 67:73-81.

Linsenmeier, A.W., U. Loos, and O. Lohnertz. 2008. Must composition and nitrogen uptake in a long-term trial as affected by timing of nitrogen fertilization in a cool-climate Riesling vineyard. Amer. J. Enol. Viticult. 59:255-264.

Lohnertz, O. 1991. Soil nitrogen and the uptake of nitrogen in grapevines. Intl. Symp. Nitrogen in Grapes and Wine, American Society for Enology and Viticulture, Davis, CA.

Mengel, K. 2002. Alternative or complementary role of foliar supply in mineral nutrition. Acta Hort. 594:33-47.

Neilsen, G.H., D. Neilsen, P. Bowen, C. Bogdanoff, and K. Usher. 2010. Effect of timing, rate and form of $\mathrm{N}$ fertilization on nutrition, vigor, yield, and berry yeast-assimilable $\mathrm{N}$ of grape. Amer. J. Enol. Viticult. 61:327-336.

OIV (Organisation Internationale de la Vigne et du Vin). 1996. Resolution Viti 4/95. Diagnostic foliaire: Une méthode harmonisée. Bull. OIV 68:35-40.

OIV (Organisation Internationale de la Vigne et du Vin). 2013. International Code of Oenological Practices. OIV, Paris.

Peacock, W.L., L.P. Christensen, and D.J. Hirschfelt. 1991. Influence of timing of nitrogen fertilizer aplication on grapevines in the San Joaquin Valley. Amer. J. Enol. Viticult. 42:322-326.

Porro, D., D. Bertoldi, C. Dorigatti, F. Camin, and L. Zille. 2010. Assorbimento fogliare di diverse forme azotate e relativa ripartizione. Acta Italus Hortus. 3:42-46.

Porro, D., C. Dorigatti, M. Stefanini, and M. Policarpo. 2006. Foliar nitrogen composition and application timing influence nitrogen uptake by, as well as partitioning within two grapevine cultivars. Acta Hort. 721: $245-250$

Portu, J., L. Gonzalez-Arenzana, I. HermosínGutierrez, P. Santamaría, and T. Garde-Cerdan. 2015a. Phenylalanine and urea foliar applications to grapevine: Effect on wine phenolic content. Food Chem. 180:55-63.

Portu, J., I. Lopez-Alfaro, S. Gomez-Alonso, R. Lopez, and T. Garde-Cerdan. 2015b. Changes on grape phenolic composition induced by grapevine foliar applications of phenylalanine and urea. Food Chem. 180: 171-180.

Schreiber, A.T., N. Merkt, R. Bleich, and R. Fox. 2002. Distribution of foliar applied labelled nitrogen in grapevines (Vitis vinifera L., cv. Riesling). Acta Hort. 594:139-148.

Schreiner, R.P., C.F. Scagel, and J. Lee. 2014. N, P, and K supply to Pinot noir grapevines: Impact on berry phenolics and free amino acids. Amer. J. Enol. Viticult. 65:43-49.

Smart, R. and M. Robinson. 1991. Sunlight into wine: A handbook for winegrape canopy management. Winetitles, Adelaide, Australia.

Spayd, S.E., R.L. Wample, R.G. Evans, R.G. Stevens, B.J. Seymour, and C.W. Nagel. 1994. 
Nitrogen fertilization of White Riesling grapes in Washington. Must and wine composition. Amer. J. Enol. Viticult. 45:34-42.

Spayd, S.E., R.L. Wample, R.G. Stevens, R.G. Evansband, and K.W. Kawakami. 1993. Nitrogen fertilization of White Riesling grapes in Washington: Effects on petiole nutrient concentration, yield, yield components, and vegetative growth. Amer. J. Enol. Viticult. 44:378-386.
Taillandier, P., F.R. Portugal, A. Fuster, and P. Strehaiano. 2007. Effect of ammonium concentration on alcohol fermentation kinetics by wine yeasts for high sugar content. Food Microbiol. 24:95-100.

Tozzini, L., P. Sabbatini, and G.S. Howell. 2013. Increasing nitrogen availability at veraison through foliar applications: Implications for leaf assimilation and fruit ripening under source limitation in Chardonnay (Vitis vinifera L.) grapevines. HortScience 48: 608-613.

Wermelinger, B. and W. Koblet. 1990. Seasonal growth and nitrogen distribution in grapevine leaves, shoots and grapes. Vitis 29:15-26.

Xia, G. and L. Cheng. 2004. Foliar urea application in the fall affects both nitrogen and carbon storage in young Concord grapevines grown under a wide range of nitrogen supply. J. Amer. Soc. Hort. Sci. 129:653-659. 